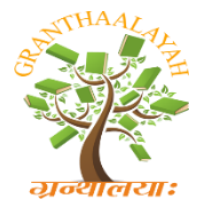

\author{
INTERNATIONAL JOURNAL OF RESEARCH - \\ GRANTHAALAYAH \\ A knowledge Repository
}

Science

\title{
ELEMENTAL AND MEDICINAL EVALUATION OF THE LEAF EXTRACT OF PILOSTIGMA RETICULATUM (DC) HOCHST
}

\author{
O. Adeyanju ${ }^{1}$, S. V. Francis ${ }^{2}$, R. R. Ede ${ }^{2}$, P.S. Jang ${ }^{2}$, J.K. Bulus ${ }^{3}$ \\ ${ }^{1,2}$ Department of Chemistry, Faculty of Natural Sciences, University of Jos, Nigeria \\ ${ }^{3}$ Department of Science Laboratory Technology, Federal college of Forestry, Jos. Nigeria
}

\begin{abstract}
Elemental analysis, phytochemical screening and antimicrobial activities of aqueous and ethanolic leaf extract of Pilostigma reticulatum (dc) Hochst were studied using paper disc diffusion method against Streptococcus pyogen, Escherichia coli and Salmonella thvpi. Elemental analysis of the plant sample revealed the presence of $\mathrm{Ca}(1.51 \pm 0.01 \mu \mathrm{g} / \mathrm{g}), \mathrm{Mg}(0.43 \pm 0.02 \mu \mathrm{g} / \mathrm{g}) . \mathrm{P}(0.29 \pm 0.01$ $\mu \mathrm{g} / \mathrm{g}), \mathrm{Mn}(3.01 \pm 0.01 \mu \mathrm{g} / \mathrm{g}), \mathrm{Fe}(1.04 \pm 0.01 \mu \mathrm{g} / \mathrm{g}), \mathrm{Zn}(1.05 \pm 0.02$ and $\mathrm{Cu}$ was below detectable limit(BDL).The results of the antimicrobial studies indicated that the extracts inhibited the growth of one or more tested pathogens. The ethanolic extract showed a broad spectrum of antimicrobial activity. Phytochemical investigation revealed the presence of tannins, alkaloids, glycosides, flavonoids, carbohydrates and terpenes. Anthraquinone and saponin were not present. Inhibition zone by the extract ranges from $4.0 \mathrm{~mm}$ to $30 \mathrm{~mm}$. The minimum inhibitory concentration (MIC) ranges from $8.0 \times 10^{2} \mu \mathrm{g} / \mathrm{ml}$ to $1 \times 10^{4} \mu \mathrm{g} / \mathrm{ml}$. Pilostigma reticulatum leaf may be able to produce antimicrobial agents in drug delivery.
\end{abstract}

Keywords: Medicinal Plant; Antimicrobial Activity; Phytochemcial Screening; Pilostigma Reticulatum.

Cite This Article: O. Adeyanju, S. V. Francis, R. R. Ede, P.S. Jang, and J.K. Bulus. (2019). "ELEMENTAL AND MEDICINAL EVALUATION OF THE LEAF EXTRACT OF PILOSTIGMA RETICULATUM (DC) HOCHST." International Journal of Research - Granthaalayah, 7(7), 391-397. https://doi.org/10.29121/granthaalayah.v7.i7.2019.792.

\section{Introduction}

Despite the great advances witnessed in modern medicine in recent decade, plants still make an important contribution to health care (Poojary et al., 2016). The medicinal value of plants lies in some chemical substances that produce a definite physiological action on human body (Uahie et al., 2014) Medicinal plants are useful for healing as well as for curing human diseases because of the presence of phytochemical constituents in the plants. The most of these bioactive constituents of plants are alkaloids, tannins, flavonoids and phenolic compounds. (Anostro et al., 2000). Medicinal plants represent rich sources from which antimicrobial agents may be obtained. Pitostigma reticulatum (dc) Hochst (caesalpineacea) is an African medicinal plant, widely used in 
the treatment of diseases and inflammatory condition. (Burkill, 1995). The local names are semellier in French, Kargo in Hausa, Ewe Abafin in Yoruba and Okpo atu in Igbo. (Awe and Omojasola, 2009). The active principles of many drugs found in plants are secondary metabolites as stated earlier, therefore basic phytochemical constituents is also vital. In the present study, Elemental analysis of the leaf was determined. Also Ethanolic and aqueous leaf extracts of P. reticulatum were screened for their phytochemcial constituents and antimicrobial activities against streptococcus pyogen, Escherichia coli and Salmonella typhi respectively. The results of this present research is likely to highlight the elemental concentration and medicinal importance of the leaf of P. reticulatum.

\section{Materials and Methods}

Plant used for this study was collected from Maiduguri metropolis, Borno State, Nigeria. The plant materials were identified by Professor S. S. Sanusi of the Biological Science Department, University of Maiduguri and a Voucher specimen No. 46BA was deposited in the research laboratory of chemistry Department, University of Maiduguri, Nigeria.

\subsection{Elemental Determination}

Five grams $(5 \mathrm{~g})$ of oven dried samples was weighed into a crucible. The crucible was then placed in a hot furnace and ashed at $600{ }^{\circ} \mathrm{C}$ for $3 \mathrm{~h}$. The furnace was cooled to about $120{ }^{\circ} \mathrm{C}$. the crucible was then removed and placed in a desiccator for $1 \mathrm{~h}$ to cool before weighing. The process was repeated until a constant weight was obtained. The ashed sample $(0.5 \mathrm{~g})$ was weighed and transferred into the digestion tube. $5 \mathrm{ml}$ each of distilled water, concentrated trioxonitrate $(\mathrm{V})$ acid (HN03) and perchloric acid (HCIO4) were added and the content mixed. The tubes were placed into the digestion block inside a fume cupboard and the temperature

\subsection{Preparation of Plants Extracts}

The plant material was dried at room temperature and then powdered using a grinder. The powdered sample (100 g) was subjected to soxhlet extraction using $300 \mathrm{ml}$ of each of the solvents (water and ethanol). The resulting extracts were concentrated on a hot water bath and kept for further investigation.

\subsection{Phytochemical Screening}

Phytochemical screening for major constituents was undertaken using standard qualitative methods. The extracts were screened for the presence of glycosides, alkaloids, tannins, flavonaids, saponins, anthraquinones and terpenes.

\subsection{Test Organisms}

Standard strain of S.pyogen, E. Coli and Salmonella typhi were obtained from the department of medical microbiology, university of Maiduguri teaching hospital, Maiduguri, Nigeria. 


\subsection{Antimicrobial Screening Test}

The paper disc diffusion method was used to determine the antimicrobial activity of the extract from P. reticulatum (dc) Hochst using standard procedures (Erickson et al., 1960; Bauer et al., 1996). Solutions of the extract of varying concentrations, ranging from 200 to $500 \mathrm{mg} / \mathrm{ml}$ were prepared. Nutrient agar was prepared, sterilized and used as the growth medium for the microorganisms. $20 \mathrm{ml}$ of sterilized medium was poured into each sterilized petri-dish covered and allowed to solidify. The Mueller-Hinton sensitivity agar plate was then seeded with the test microorganisms by the spread plate technique, and was left for about 30 minutes to dry. The sterilized paper discs were soaked in the prepared solution of the extracts with varying concentration and were dried at $50^{\circ} \mathrm{C}$. The dried paper discs were then planted on the nutrient Agar seeded with the test microorganisms. The plates were incubated at $37^{\circ} \mathrm{C}$ for $24 \mathrm{~h}$ and then inspected for zones of inhibition of growth. The zones of inhibition were measured and recorded in millimeters. A control experiment was also set up using pure DMSO for each tested organisms.

\subsection{Determination of Minimum Inhibitory Concentration (MIC)}

MIC of the ethanolic and aqueous extract of P. reticulatum (MIC) hochst which showed the highest antibacterial activity in the disc diffusion assay were determined based on broth dilution technique with a standard method (Krivoshan et al., 1989). The inocula of microorganisms were prepared from $12 \mathrm{~h}$ broth cultures. Stock solutions of extracts $(200 \mathrm{mg} / \mathrm{ml})$ were diluted with nutrient broth cultures. Stock solutions of extracts $(200 \mathrm{mg} / \mathrm{ml})$ were diluted with nutrient broth in serial tenfold dilutions using nutrient broth to make dilution ranging from $200 \mathrm{mg} / \mathrm{ml}(2 \times 105 \mu \mathrm{g} / \mathrm{ml})$ to $0.2 \mathrm{mg} / \mathrm{ml}$ $(2 \times 102 \mu \mathrm{g} / \mathrm{ml})$ and inoculated with $0.2 \mathrm{ml}$ of the test microorganisms. The inoculated tubes were then incubated at $370 \mathrm{C}$ for $24 \mathrm{~h}$ and were inspected for non-turbidity. The last concentration of the extract which prevented visible growth was noted and recorded as minimum inhibitory concentration (MIC).

\section{Results}

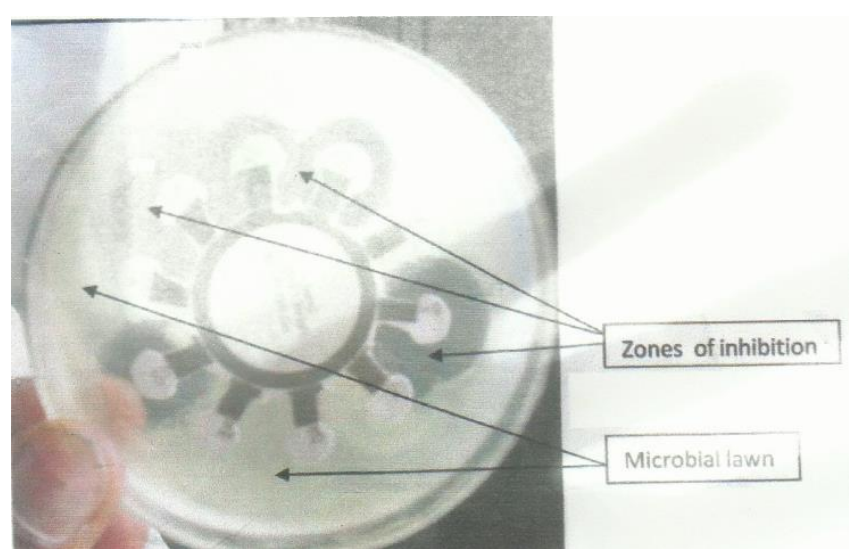

Figure 1: Inhibition zones and microbial Lawn

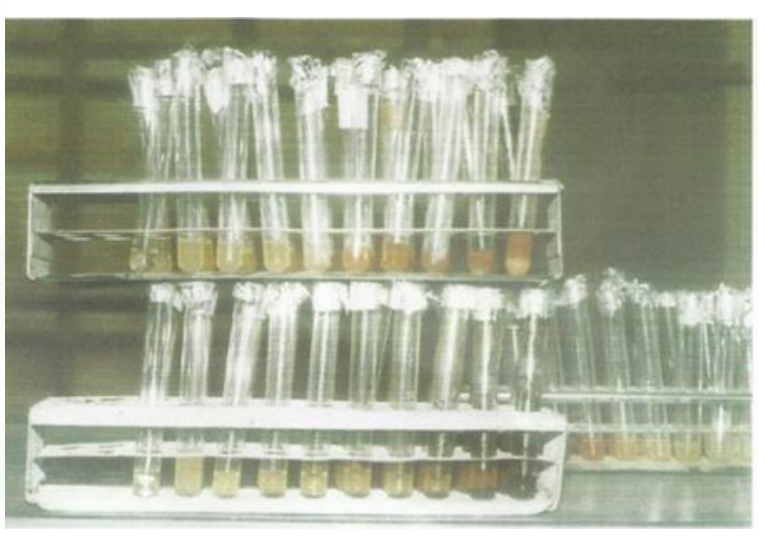

Figure 2: MIC Determination

The results of the elemental analysis, phytochemical screening, antimicrobial tests and minimum inhibitory concentrations for the water and ethanolic extracts are presented in Tables 1 to 6. 


\subsection{Elemental Analysis}

The elemental analysis results in table 1 shows that calcium, $(\mathrm{Ca})$, Magnesium $(\mathrm{Mg})$, Iron $(\mathrm{Fe})$, Zinc (Zn), Manganese (Mn) and Phosphrous (P) were present at moderate concentrations.

Table 1: Elemental analysis of the Leaf of P.reticulatum

\begin{tabular}{|l|c|c|c|c|c|c|c|}
\hline \multicolumn{1}{|c|}{ Elements } & $\mathbf{C a}$ & $\mathbf{M g}$ & $\mathbf{M n}$ & $\mathbf{F e}$ & $\mathbf{C u}$ & $\mathbf{Z n}$ & $\mathbf{P}$ \\
\hline $\begin{array}{l}\text { Concentration } \\
(\mathrm{mg} / \mathrm{g})\end{array}$ & $1.5 \pm 0.01$ & $0.43 \pm 0.02$ & $3.01 \pm 0.01$ & $1.04 \pm 0.01$ & $\mathrm{BDL}$ & $1.05 \pm 0.02$ & $0.29 \pm 0.01$ \\
\hline
\end{tabular}

$\mathrm{BDL}=$ Below detectable limit; Results are means of triplicate determination \pm standard deviation.

Table 2: Phytochemical screening of Pilostigma reticulatum (dc) hochst water and ethanolic leaf extracts.

\begin{tabular}{|l|l|l|}
\hline Phytochemicals & Water extract & Ethanolic extract \\
\hline Tannins & + & ++ \\
\hline Carbohydrate & + & + \\
\hline Alkaloids & + & ++ \\
\hline Glycoside & + & ++ \\
\hline Flavonoid & ++ & ++ \\
\hline Terpenes & + & ++ \\
\hline Saponins & - & - \\
\hline Anthraquinones & - & - \\
\hline
\end{tabular}

+++=High concentration; ++ = moderate concentration, $+=$ low concentration; $-=$ absent.

Table 3: Inhibition zone of Pilostigma reticulatum (dc) hochst water extract against the tested micro organisms.

\begin{tabular}{|l|l|l|l|}
\hline \multicolumn{5}{|c|}{ Zone of Inhibition (mm) } \\
\hline Extract/drug (mg/ml) & Streptococcus pyogen & E. coli & Salmonella typhi \\
\hline 200 & $4 \pm 0.01$ & $12 \pm 0.02$ & $00 \pm 0.02$ \\
\hline 300 & $7 \pm 0.01$ & $15 \pm 0.01$ & $24 \pm 0.02$ \\
\hline 400 & $10 \pm 0.04$ & $15 \pm 0.01$ & $26 \pm 0.01$ \\
\hline 500 & $13 \pm 0.01$ & $18 \pm 0.02$ & $30 \pm 0.04$ \\
\hline 250 GTC & $22 \pm 0.02$ & $25 \pm 0.03$ & $32 \pm 0.04$ \\
\hline
\end{tabular}

GTC $=$ Gentamicin, Results are means of triplicate determination \pm standard deviation .

Table 4: Inhibition zone of Pilostigma reticulatum (dc) ethanol extract against the tested microorganisms.

\begin{tabular}{|l|l|l|l|}
\hline Extract/drug (mg/ml) & Streptococcus pyogen & E. coli & Salmonella typhi \\
\hline 200 & $4 \pm 0.00$ & $17 \pm 0.03$ & $17 \pm 0.02$ \\
\hline 300 & $4 \pm 0.04$ & $17 \pm 0.01$ & $15 \pm 0.01$ \\
\hline 400 & $8 \pm 0.00$ & $19 \pm 0.01$ & $19 \pm 0.04$ \\
\hline 500 & $10 \pm 0.02$ & $21 \pm 0.02$ & $20 \pm 0.01$ \\
\hline 250 GTC & $25 \pm 0.01$ & $25 \pm 0.01$ & $23 \pm 0.02$ \\
\hline
\end{tabular}

GTC $=$ Gentamicin, Results are means of triplicate determination \pm standard deviation. 
Table 5: Minimum inhibitory concentration (MIC) of Pilostigma reticulatum (dc) (water extract) against the tested microorganisms

\begin{tabular}{|l|l|l|l|l|l|}
\hline \multirow{2}{*}{ Extract/drug $(\mathbf{m g} / \mathbf{m l})$} & \multicolumn{5}{|c|}{ Concentration $\boldsymbol{\mu g} / \mathbf{m l}$} \\
\cline { 2 - 6 } & $\mathbf{8 x 1 0}^{2}$ & $\mathbf{2 x 1 0}^{3}$ & $\mathbf{3 x 1 0}^{\mathbf{3}}$ & $\mathbf{6 x 1 0 ^ { 3 }}$ & $\mathbf{1 x 1 0}^{\mathbf{4}}$ \\
\hline Streptococcus pyogen & - & - & - & - & $\mathrm{O}+$ \\
\hline Escherichia coli & - & - & - & $\mathrm{O}+$ & + \\
\hline Salmonella typhi & - & $\mathrm{O}+$ & + & + & + \\
\hline
\end{tabular}

$+=$ inhibition, $\mathrm{O}+=$ minimum inhibition, $-=$ no inhibition

Table 6: Minimum inhibitory concentration (MIC) of Pilostigma retidulatum (dc) (ethanol extract) against the tested microorganism

\begin{tabular}{|l|l|l|l|l|l|}
\hline \multirow{2}{*}{ Extract/drug $(\mathbf{m g} / \mathbf{m l})$} & \multicolumn{5}{|c|}{ Concentration $\boldsymbol{\mu g} / \mathbf{m l}$} \\
\cline { 2 - 6 } & $\mathbf{8 x 1 0}^{\mathbf{2}}$ & $\mathbf{2 \times 1 0 ^ { 3 }}$ & $\mathbf{3 \times 1 0 ^ { 3 }}$ & $\mathbf{6 x 1 0 ^ { 3 }}$ & $\mathbf{1 x 1 0}^{\mathbf{4}}$ \\
\hline Streptococcus pyogen & - & - & - & - & $\mathrm{O}+$ \\
\hline Escherichia coli & - & $\mathrm{O}+$ & + & + & + \\
\hline Salmonella typhi & - & - & + & $\mathrm{O}+$ & + \\
\hline
\end{tabular}

$+=$ inhibition, $\mathrm{O}+=$ minimum inhibition, $-=$ no inhibition

\section{Discussion}

The elemental analysis results (table 1) shows that the presence of calcium, magnesium, Iron, zinc, manganese and phosphorus at different concentration. The concentration of the essential elements appear to be lower and within the safety limit according to W.H.O. (1996). The low concentration of Iron $(\mathrm{Fe})$, Zinc $(\mathrm{Zn})$ and absence of Copper $(\mathrm{Cu})$ is an indication of little or no toxicity of plants as heavy metals are known to cause cancer, liver and kidney problems. (Ogugbuaja, et., al., 1997).

The phytochemical screening (Table 2) revealed presence of Tannins, alkaloids, glycoside, flavonoid terpenes. The chemical constituents present in extract have many therapeutic values. Tannins are metabolites well known for their antimicrobial properties (Tsechesche, 1971). Flavonoids have both antifungal and antibacterial activities. They possess anti-inflamatory activity (Ogundaini, 2005) Flavonoids, terpenes and steroids are known to have antimicrobial and bactericidal properties against several pathogens (Usman et al., 2007; Hassan et al., 2004). In the antimicrobial studies, the majority of the organisms were more sensitive to the ethanol leaf extract of P. reticulatum (dc) hochst. According to Trease and Evans (1978), the anti-bacterial activity and inhibitory effect of plant extracts may be due to the presence of secondary metabolites.

In Table 6, the ethanol extract of $\mathrm{P}$. reticulatum (dc) hochst was active against the entire microorganisms. S. Pyogen, E. coli and S. typhi. It has MIC value of $2 \times 103 \mu \mathrm{g} / \mathrm{ml}$ against E. coli and $6 \times 103 \mu \mathrm{g} / \mathrm{ml}$ against S. typhi and $1 \times 104 \mu \mathrm{g} / \mathrm{ml} \mathrm{S}$. pyogen. These findings are consistent with Etuk et. al. (2009; who reported that the bark extract of P. reticulatum had antidiarrhae activity in vivo. Previous reports have demonstrated the antidiarrheae activity of tannins (Murkherjee et. al., 1995), flavonoids (Galvez et al., 1993; and saponins (Otshudi et al., 2000). 


\section{Conclusion}

The result of the experiment showed that the P. reticulatum leaves may have some valuable antimicrobial activities against gram positive and gram negative microorganisms. This property tends to support the traditional medicinal stage in the treatment of bacterial infections. The result of the study justified the use of the plant in the treatment of diseases of microbial herbal medicine.

\section{References}

[1] Abo KA, Adeyemi AA, Jegede IA (2000). Spectrophotometric estimation of anthraquinone content and antimicrobial potential extracts of some cassia species used in herbal medicine in Ibadan, Nigeria Sci. Forum, 3(2): 57-63.

[2] Abo KA, Lasaki SW, Adeyemi AA (1999). Laxative and antimicrobial properties of cassia species growing in Ibadan, Nigeria J. of natural product and medicine, 8: 47-50.

[3] Ahmad AB (2006). Phytochemical screening of cassia genera for quinines and anthraquinones, unpublished B.Sc Chemistry dissertation University of Maiduguri.

[4] Awe S. and Omojasola, P. F. (2009). A comparative study of the antibacterial act of P. R back extract with some antibiotics. Ehnobatatrical leaflets 13: $1197-1204$.

[5] Bauer AW, Kilby NM, Sherris JC, Turck M (1996). Antibiotics susceptibility testing by a standardize single paper disc. J. Clin. Pathol., 45: 473-496.

[6] Bonja C, Farrokhi K (2004). The bactericidal activities of amoxicillin with other antimicrobial agent. J. Antimicrob. Chemother., 3: 273.

[7] Burkill HM (1995). The useful plants of west African 2n Edn, Vol 3, royal Kew Botanical Garden, Kew, London, pp. 144-150. Dalziel JM (1956). Useful plants of West Tropical African Crown agents for Overseas Government; London.

[8] Elujoba AA, Abere AT, Adelusi SA (1999). Laxative activities of cassia Erickson HC, Tuneral O, Wickman K (1960). The paper disc method for determination of bacteria sensitivity of Antibiotics. J. Clin. Lab. Invest., 12: 44-45.

[9] Etuk EU, Ugwah WIN, Ajagbonna OP, Onyeyili PA (2009). Ethnobotonical su-vey and preliminary evaluation of medicinal plants with antidiarrhoea properties in Sokoto, Nigeria.

[10] Fadeyi M (1983). A handbook on traditional medicine practices in Nigeria. Longman Nigeria, $p$. 35. Galvez J, Zarzuelo A, Crespo ME, Lorente MD, Ocete MA, Jmene ZJ (1993). Antidiarroeal activity of Euphobia extract and isolation of active flavonoids content. Planta Medica, 59: 333-336.

[11] Hassan MA, Oyewale AO, Amupitan JO, Abdullahi MS, Okonkwo EM (2004). Prelimirary phytochemical and antimicrobial Investigation of crude extract of root bark of Deterium Microcarpum J. Chem. Sci., Niger., 29: 36-49.

[12] Iwu MM, Angela RD, Chris O (1999). New microbials of plant origin in j. janic (ed).

[13] Krivoshien, YS (1989). Handbook on Microbiology Russia publisher, pp. 36.

[14] Lambo JO (1979). The healing power of herbs with special reference to obstetric and Gynecology In Africa medicinal (2nd edition) E.A PRESS Nigeria, pp. 24-27.

[15] Mukherjee PK, Das J, Balasubrami R, Saha K, Pal M, Saha PM (1995) Antidiarrhoeal evaluation of nelumbe nucifera rhizome extract. Ir J. Pharmacol., 22: 262-268.

[16] Nostro, A., Germano, M. P., Dangelo, V., Marino, A. A., Cannatelli, M. A. (2000). Extactration methods and bioautography for evaluation of medicinal plant antimicrobial xriciry. Lett. Appl. Microbial, 30: 379 - 384

[17] Ogarawu V (1992). Studies in natural product chemis the antimicrobial activity of Senegalensis, M.sc dissertation preser the Department of Chemistry, University of Maiduguri.

[18] Ogugbuaja, V. O. Akinniyi, J. A., Abdulrahman, F. I. and Ogarawu, V. C. (1997). Element contents of medical plants. A monograph. Department of chemistry Faculty of Sciences, University of Maiduguri, Nigeria. 
[19] Otsusi AL, Foriers A, Vercrysee A, Van Zeebrock A (2000). In vitro antimicrobial activity of six medicinal plant traditionally used for treatment of dysentery and diarrhea in democratic republic of Co (DRC) Phytomedicine, 7:162-172.

[20] Perspective on new crops and uses. ASHS press mexandria, pp.462.

[21] Poojary, R. Kumar, N.A. Kumarachandra, R. Saryeev, C. R. (2016). Evaluation of in. vrtro antioreidant properties of Hydro Alcoholic extract of Entire plant of cynod. Dactylon. J. young pharm. 8 (4). $378-384$.

[22] Trease GE, Evans WC (1978). Pharmacognosy 11th edition Baillier tindal, London, pp. 386-388, 480, 509, 540.

[23] Uahie, O., A. Adamu, H. M., Abayeh O. J., Lawal, U. (2014). Phytochemical screening of (Chrysophyllumalbidum) leaf extracts. J. of applied chemistry, 2 (2): 38 - 44.

[24] Usman H, Abdulrahaman Fl, Ladan AA (2007). Phytochemical antimicrobial Evaluation of Tribuius terrestrisi. L (Zygophylaceae) Growing in Nigeria Res. J. BIOSC. Medwell, 2(3): 244247.

[25] W.H.O. (1996). Guidelines for elements in health and human nutrition. $50-68$.

\footnotetext{
*Corresponding author.

E-mail address: adeyanju.olusola@yahoo.com
} 